\title{
POSSIBILITIES OF DIAGNOSTICS OF SOCIAL SKILLS OF PRESCHOOL CHILDREN
}

\section{[MOZNOSTI DIAGNOSTIKY SOCIALNI KOMPETENCE PREDSKOLNICH DETI]}

\author{
Katerina Kubikova - Milan Podpera - Aneta Bohacova
}

doi: 10.18355/PG.2020.9.2.9

\begin{abstract}
The study focuses on the pilot verification of the COR Observation Items Preschool Child Observation Record (2003) adapted to the Czech environment and presents a pilot analysis of the social skills of children in selected kindergartens. Data from observations of 153 children from selected kindergartens were used for the analysis. The study confirms the possibility of using the tool for diagnosing children's social skills in kindergarten. The tool responds sensitively to the age and gender differences of children and class homogeneity.
\end{abstract}

\section{Key words}

social competence, pedagogical diagnostics, preschool child, observation, teacher

\section{Anotace}

Studie se zaměřuje na pilotní ověření pozorovacího archu COR Observation Items - Preschool Child Observation Record (2003) přizpůsobeného českému prostř̌edí a představuje pilotní analýzu sociálních dovedností dětí na vybraných mateřských školách. Pro analýzu byla použita data z pozorování 153 dětí z vybraných mateřských škol. Studie potvrzuje možnost použití nástroje pro diagnostiku sociálních dovedností dětí v mateřské škole, nástroj citlivě reaguje na věkové a genderové odlišnosti dětí a homogenitu tř́idy.

\section{Klíčová slova}

sociální kompetence, pedagogická diagnostika, předškolní dítě, pozorování

\section{Úvod}

V současné době se svět kolem nás neustále mění a připravujeme děti na do jisté míry nepředvídatelnou budoucnost, jejiž podobu si dokážeme představit pouze $\mathrm{v}$ hrubých rysech. Právě proto je nutné vybavit dětmi takovými dovednostmi v oblasti sociálních dovedností, které budou zvyšovat jak jejich odolnost, tak i sebeuvědomění. Mateřskou školu lze chápat jako instituci, která uvádí předškolní děti do sociokulturního světa a kde dochází k rozvoji osobnosti, hodnot a přijetí společenských norem (Helus, 2007). Reprezentuje počátek systematického výchovného působení. Prostředí mateřské školy poskytuje ideální podmínky a př́ležitosti $\mathrm{k}$ individualizovanému, osobnostně zaměřenému působení na dítě (Opravilová, 2016). Výchovné působení učitelů už $\mathrm{v}$ předškolním vzdělávání tvoří základ pro rozvoj sociálních 
dovedností a může podstatným způsobem ovlivnit, at' už pozitivně nebo negativně, formování sebeuvědomění dítěte.

I vzhledem k tomu, že je předškolní vzdělávání důsledně vázáno $\mathrm{k}$ individuálně různým potřebám a možnostem jednotlivých dětí, je potřeba, aby působení učitele vycházelo z pedagogické diagnostiky (RVP PV, 2018). Učitelská profese tak klade stále větší nároky na pedagogickou diagnostiku rozvoje dětí (např. Syslová, 2013; Syslová, 2017; Svobodová, 2017). Základní metodou pedagogické diagnostiky předškolního dítěte je pozorování, které přináší učiteli ucelené informace o dítěti, pokud je prováděno správně. Ve stati představujeme učitelům nástroj, který může nejen pomoci s určením míry rozvoje kompetencí dítěte, ale i s možnostmi dalšího rozvoje sociálních kompetencí.

\section{Teoretické zakotvení}

V předškolním věku je sociální interakce s dospělými hlavním zdrojem získávání informací o sobě, proto způsob, jakým jsou sociálně hodnoceny, tvoří základ pro tvorbu sebeuvědomění. Jak rostou, zóna působení, ve které se tyto interakce uskutečňují, se postupně rozšiřuje. U předškolních dětí je však také důležité, jak probíhá interakce s dospělými. Mnoho podnětů, které si dítě nedovede vysvětlit, může být vysvětleno dospělým tzv. proxy control (Bandura, 1997). Práce učitele v předškolním vzdělávání by měla být cílena na děti nejenom z hlediska rozvoje školních dovedností, ale důležité je také to, jaký mají vliv na sebeuvědomění dětí. V teoretických statích (Bandura, 1997; Deci \& Ryan 1980; Nicholls, 1984; Elliot, 1997) se autoři shodují na tom, že pro rozvoj sociálních dovedností a psychické odolnosti velmi úspěšně funguje řízená zkušenost se zvládnutím problémové situace $\mathrm{v}$ sociálním kontextu. Právě sociální dovednosti a psychickou odolnost považujeme za stěžejní aspekty nutné pro zvládnutí nároků školní docházky a rozvoj výkonové motivace, která velmi úzce souvisí se sociálními dovednostmi a predikuje žákovu úspěšnosti při studiu. Tento fakt podporují výsledky výzkumů z oblasti žákovského výkonu na školách, které naznačily, že úroveň výkonové motivace se začne snižovat už na základní škole a tento negativní trend pokračuje po celou studijní kariéru právě díky nedostatečně rozvinutému pozitivnímu sebeuvědomění (Eccles, Wigfield, Harold \& Blemenfeld, 1993).

Vzhledem $\mathrm{k}$ výše zmíněným rámcovým předpokladům můžeme konstatovat, že rozvoj sociálních kompetencí během sekundární socializace v mateřské škole je jedním ze základních kamenů přípravy dítěte na školní vzdělávání. V dalším textu budeme podrobněji věnovat problematice sociálních kompetencí ve vztahu $\mathrm{k}$ rozvoji dětské osobnosti a připravenosti na školní docházku právě s ohledem na design výzkumu, který představujeme.

V další analýze teorií rozvoje sociálních kompetenci narazíme na koncept tzv. pozitivního přijetí (afiliace). Pozitivní přijetí označuje typ sociální interakce, která je zásadní pro socializaci jedince, a jejímž cílem je usilovat o kontakt $\mathrm{s}$ dř́ve neznámými nebo málo známými jedinci, a udržovat tento kontakt způsobem, který obě strany prožívají jako uspokojující, stimulující a obohacující. Motiv je pak aktivován kdykoli jedinec přijde do styku a komunikuje s neznámými nebo málo známými lidmi. Motiv affiliace člověka 
$\mathrm{v}$ podstatě vede $\mathrm{k}$ tomu, aby se $\mathrm{s}$ cizími lidmi seznámil, komunikoval, a udržovali s nimi kontakt i v budoucnosti. (Mehrabian, 1970; Winter, 1993; Schüller, 2002). Z vývojového hlediska jsou zkušenosti nabyté s vytvářením sociálních vztahů zejména $\mathrm{v}$ dětství nutné pro pozitivní rozvoj sociálního chování $\mathrm{V}$ sekundárních sociálních skupinách. Experimentální studie prokázaly, že potřeba afiliace je běžně aktivována $\mathrm{v}$ situacích strachu (v nebezpečných situacích, zkouškách, hodnoceních, nových a nejistých situacích) a právě tendence spojovat síly s ostatními funguje jako prostředek zvládání nepř́ijemných emocí strachu a nejistoty. (McAdams, 1982)

Velkou metodologickou výzvou je provádění výzkumů u dětí předškolního věku. Studie provedené u dětí ve věku 3 - 6 let, poskytly zásadní zjištění, že předškolní děti mají stále velmi rozptýlené chápání schopností vlastních i druhých (Dweck, 2002; Heyman a kol., 2003). Např. na otázku, jak poznají, zda je jiné dítě chytré, předškolní děti často odkazují na přátelskost a dobré chování dítěte (Stipek \& Tannatt, 1984; Stipek \& Daniels, 1990). Zdá se, že pro děti tohoto věku je důležitější určit, zda jsou jejich vrstevníci přátelští a slušní, než zda jsou v každodenním sociálním srovnání schopní nebo inteligentní (Frey \& Ruble, 1985). Předškolní děti mají také tendenci zaměňovat dimenze, jako je např. inteligence za dobré chování, nebo vstř́ínost a laskavost (Heyman, Dweck, \& Cain, 1992; Stipek \& Daniels, 1990; Stipek \& Tannatt, 1984; Yussen \& Kane, 1985). Stipek a Daniels (1990) zjistili, že mnozí probandi z předškolních zařízení, si mysleli, že děti, které dobře čtou, jsou zároveň přátelské a jsou schopny přeskakovat vyšší překážky. Navíc odhady vlastních schopností jsou u předškolních dětí obvykle také velmi optimistické; většina dětí tohoto věku věří, že jsou nejlepší ve tř́idě (Beneson \& Dweck, 1986).

Ukazuje se, že v předškolním věku je rozvoj sociálních kompetencí jeden ze stěžejních bodů sociálně psychologického vývoje jedince. Zmíněné studie odkazují na fakt, že sekundární sociální rozvoj (socializace mimo rodinu) hraje důležitou roli pro rozvíjení nejen sociálních interakcí, ale tvoří neodmyslitelný základ pro rozvoj výkonového chování dítěte, odolnost $\mathrm{v}$ zátěžových situacích. S nástupem do mateřské školy modifikuje dítě své chování podle požadavků dalších osob tentokrát mimo rodinu. Pro dítě to neznamená změnu rolí, ale jen další roli navíc. Dítě se učí navazovat kontakt a komunikovat jak na úrovni rovnocenných partnerů (komunikace $\mathrm{s}$ vrstevníky), tak i s neznámými dospělými (učitelé v MŠ). Dosažení dobré pozice a sympatie u (vrstevníků) kamarádů je důležité pro potvrzení pozitivní hodnoty vlastní osoby. Dítě získává větší sebejistotu a sebeúctu, což se projeví v jeho sebepojetí

Jak jsme již zmínili, hlavním nástrojem poznávání dítěte je pro učitele mateřské školy pozorování. Jeho výhodou je možnost zachytit a popsat, co se ve třŕdě děje a většinou velmi málo narušuje sociální interakci a klima třídy. Za hlavní př́nos považujeme to, že učitel je schopen zachytit situace, které považuje za důležité. Může objevit nové jevy a vztahy, které neočekával, či si jich předem nebyl vědom. Aby byl učitel schopen efektivně sledovat všechny pozorované jevy, je dobré pracovat s předem připraveným pozorovacím archem (Švaříček a kol., 2007). Protože je poměrně náročné takový arch sestavit, rozhodli jsme se představit diagnostický nástroj pro učitele 
modifikovaného pro české prostředí z metodického materiálu High/Scope Press - COR Observation Items - Preschool Child Observation Record (2003). Jedná se o pozorovací arch, který pomáhá učitelů zjistit, na jaké úrovni rozvoje sociálních kompetencí se dítě nachází. Současně nabízí přehled úrovní, kterými by mělo dítě projít a jaké úrovně dosáhnout před nástupem školní docházky (v České republice nastupují děti do školy po dovršení 6 roku věku).

\section{Cíle studie a výzkumné předpoklady}

Hlavním cílem studie bylo přizpůsobit pozorovací arch českému prostředí a pilotně ověřit jeho validitu. Rozhodli jsme se ověřit možnosti využití pozorovacího archu na náhodně vybraných mateřských školách.

V rámci exploračního výzkumu byly ověřovány dva vstupní výchozí předpoklady, které byly pro potřeby statistické analýzy rozděleny do několika přesně formulovaných výzkumných otázek. Statistické hypotézy zde neuvádíme, nebot’ jejich specifikace zrretelně vychází z formulace věcných hypotéz a užitého testu signifikance. Cílem exploračního výzkumu je ověřit zvolenou metodu měření sociálních kompetencí, a tedy prvotně potvrdit význam následujících předpokladů $(\mathrm{P})$.

P1: Děti dosahují odlišného skóre $\mathrm{v}$ jednotlivých subtestech baterie v závislosti na věku, pohlaví, délce školní docházky do MŠ, počtu dětí ve třídě a věkového složení třídy (heterogenní/homogenní).

P2: Se zvyšující se úrovní (skórem) dovednosti v jednom subtestu roste úroveň (skóre) dovednosti v ostatních subtestech baterie.

Vzhledem k provázanosti obou subtestů předpokládáme, že jednotlivé položky (např. úroveň schopnosti řešení problémů) budou souviset i s úrovní rozvoje v položce řešení konfliktů, dětmi osvojené strategie v iniciování hry budou analogicky aplikovány v kontaktu s ostatními dětmi i dospělými; výše skóre v položce vztah k autoritám, dospělým, rodičům děti budou promítat i do vztahu k ostatním dětem nebo do společných her (nápodobou, neuvědomělou projekcí apod.). Nutno dodat, že jednotlivé subtesty baterie měří specifické sociální dovednosti a postihují tak celkovou sociální kompetenci (změřenou touto baterií). Vzhledem k tomu, že se subtesty vztahují ke společnému (nadřazenému) konstruktu „sociální kompetence,“ dá očekávat jejich vzájemná korelace.

\section{Metodologie}

\section{Pozorovací arch}

Pozorovací arch COR Observation Items - Preschool Child Observation Record (2003) vznikl jako pomoc pro učitele mateřských škol v identifikaci stupně rozvoje osobnosti dítěte. Původní americký originál obsahuje šest subtestů, my jsme pro potřeby výzkumného záměru vybrali dva (Iniciativa a Sociální dovednosti), které nejlépe odpovídají výzkumnému záměru.

Vlastní pozorovací arch je rozdělen na dva subtesty - Iniciativa během hry a Sociální dovednosti. Subtest Inciativa má tři položky - Rozhodování a plánování, Řešení problémů, Iniciování hry. Subtest Sociální dovednosti obsahuje čtyři položky - Vztah dítěte k dospělým, Vztah k ostatním dětem, Řešení konfliktů, Porozumění a vyjadřování svých pocitů. Všechny položky 
jsou rozděleny na pět možných úrovní (škála 1-5), přičemž v každá z nich popisuje stupeň rozvoje sledovaného jevu od nejnižšího po nejvyšší. Každá úroveň je $\mathrm{v}$ položce podrobně popsaná, stejně jako je charakterizována položka i celý subtest.

Uvádíme pro představu př́klad popisu položky a jednotlivých úrovní.

Subtest Iniciativa během hry

Položka Řešení problému (položka je zaměřena především na řešení problémů s pomůckami obecně, nikoliv při interakci s ostatními dětmi).

Úroveň 1 : Dítě vyjadřuje frustraci, když narazí na problém. Na této úrovni při řešení problému typicky projevuje frustraci bud' svým jednáním (házením pomůcek na podlahu, dupáním apod.), nebo hlasovými projevy (pláčem, křikem atd.). Úroveň 2: Dítě identifikuje problém a požádá o pomoc. K zařazení do této úrovně musí dítě problém rozeznat, a bud' ho samostatně pojmenovat, nebo žádostí o pomoc reagovat na podnět dospělého. Úroveň 3: Dítě se pokouší o jedno řešení problému, avšak nemusí být $\mathrm{v}$ jeho řešení úspěšné, aby bylo zařazeno do této kategorie, a to i v př́ípadě, že se pomocí stejné metody opakovaně pokouší o řešení. Úroveň 4: Dítě se pokouší alespoň o dva způsoby řešení problému. Stejně jako u předchozí úrovně, dítě nemusí být při řešení úspěšné, ale i přes opakovaný neúspěch zkouší jinou metodu řešení. Úroveň 5: Dítě se pokouší o tř̌i a více způsobů řešení problému. Aktivně se zapojuje a vytrvale, s vynaloženým úsilím, zkouší vyřrešit problém. Musí se pokusit alespoň o tři a více metod, aby problém vyřrešilo. I když je dítě př̌i řešení problému úspěšné, pro tuto úroveň není úspěch nezbytně nutný.

Překlad nástroje $\mathrm{z}$ angličtiny do češtiny probíhal následovně. Nejprve byly všechny položky přeloženy nezávisle dvěma překladateli; a oba tyto překlady byly porovnány a projednány a sjednoceny do jedné verze autory studie. Následně byla tato verze znovu přeložena do angličtiny nezávislým překladatelem a zpětný překlad byl porovnán s původní verzí a byly navrženy změny $\mathrm{v}$ českém znění. Nakonec autoři studie spolu $\mathrm{s}$ nezávislým konzultantem vytvořili finální českou verzi na základě zpětného překladu a návrhů nezávislého překladatele.

\section{Sběr dat}

Pozorování probíhala $\mathrm{v}$ rámci pedagogické praxe $\mathrm{v}$ mateřských školách. Pozorování prováděli studenti druhého a třetího ročníku bakalářského studia studijního programu Učitelství pro mateřské školy. Pozorování se konala 14 dní, každý student si náhodně (losováním) vybral jedno dítě ze třídy, které sledoval po celou dobu své praxe dle oblastí préedepsaných v pozorovacím archu. Průběžně při výskytu popisovaného jevu zaznamenával tento výskyt do pozorovacího archu. Záznamové archy následně analyzovali autoři studie.

\section{Statistická analýza dat}

Data byla analyzována ve statistickém softwaru SPSS. Normalita rozložení kardinálních (intervalových) proměnných dat byla ověrena za pomoci histogramů, P-P plotů a testem Kolmogor - Smirnov. Data se po vyhodnocení blíží modelům normálního rozložení a nevykazují významné excesy od funkce normálního rozložení. Vzhledem $\mathrm{k}$ výstupům exploračních analýz a 
velikosti výběrového souboru byly pro práci s kardinálními daty zvoleny parametrické testy.

K posouzení souvislostí mezi kategoriálními znaky souboru (věk, pohlaví, délka docházky dítěte do MŠ ad.) s dosaženými skóry v jednotlivých subtestech baterie byla využita jednofaktorová analýza rozptylu (ANOVA). Za pomoci ANOVY byl otestován výzkumný předpoklad P1. Výsledky jsou podpořeny clusterovanými intervalovými grafy.

Předpoklad P2, tj. vzájemný vztah mezi dosaženými skóry v jednotlivých subtestech baterie, byl analyzován pomocí Pearsonova korelačního koeficientu, prezentuje jej prŕśslušná matice. Výstupy korelační matice byly doplněny testováním průměrů subtestů pomocí T-testu pro párovaná data.

\section{Výzkumný vzorek}

Celkem proběhlo pozorování u 153 dětí ve věku 3 až 6 let. Z tohoto počtu bylo 78 dívek a 75 chlapců. Věkové rozložení je uvedeno v tabulce (Chyba! Nenašiel sa žiaden zdroj odkazov.). Věkově heterogenní třídu navštěvovalo 96 dětí, věkově homogenní 57 dětí. Třídy s počtem dětí menších než 25 navštěvovalo 67 respondentů, ze tříd s počtem dětí větším než 25 se výzkumu zúčastnilo 86 dětí.

\begin{tabular}{|c|c|c|c|}
\hline & \multicolumn{2}{|l|}{ Pohlaví } & \multirow{2}{*}{ Celkem } \\
\hline Věk & muž & žena & \\
\hline 3 & 14 & 12 & 26 \\
\hline 4 & 16 & 24 & 40 \\
\hline 5 & 22 & 21 & 43 \\
\hline 6 & 23 & 21 & 44 \\
\hline Celkem & 75 & 78 & 153 \\
\hline
\end{tabular}

Tabulka 1 Základní charakteristika výzkumného vzorku

Všechna data byla zpracovávána anonymně a byly dodrženy etické zásady pedagogicko-psychologického výzkumu.

\section{Výsledky}

\section{Pilotní analýza sociální kompetence}

Deskriptivní analýza (Tabulka 2) a příslušný Error Bar (Graf 1) představují průměrná skóre dosažená $\mathrm{v}$ jednotlivých položkách a subtestech pozorovacího archu COR Observation Items - Preschool Child Observation Record (2003). Komparace průměrných skórů položek v párovém tetování prokázala signifikantní rozdíly v úrovni měřené dovednosti (kompetence). Významně vyššího skóre dosahovaly děti v položkách Rozhodování $a$ plánováni a Vztah ditěte $k$ ostatním dětem ( $\mathrm{p}<.01)$, naopak významně nižšího skóre pak dosahovaly u položek Řešeni problémů a Řěsení konfliktů (p<.01). 


\begin{tabular}{|c|c|c|c|c|c|c|c|c|c|c|}
\hline Frequencies & $\begin{array}{c}\text { A. Rozhodování } \\
\text { a plánování }\end{array}$ & $\begin{array}{l}\text { B. Řešení } \\
\text { problémů }\end{array}$ & $\begin{array}{c}\text { C. Iniciování } \\
\text { hry }\end{array}$ & $\begin{array}{l}\text { 1. Iniciativa - } \\
\text { součet }\end{array}$ & A. Vztah ditǐte & e $\begin{array}{c}\text { B. Vztah ditěte } \\
\text { kostatním } \\
\text { dětem }\end{array}$ & $\begin{array}{l}\text { C. Řešení } \\
\text { konfliktu }\end{array}$ & $\begin{array}{c}\text { D. Porozuměni } \\
\begin{array}{c}\text { a vyjadřování } \\
\text { pocitů }\end{array}\end{array}$ & $\begin{array}{l}\text { 2. Sociální } \\
\text { dovednosti - } \\
\text { součet }\end{array}$ & $\begin{array}{l}\text { součet } \\
\text { celkem }\end{array}$ \\
\hline$N$ Valid & 153 & 153 & 153 & 153 & 153 & 153 & 153 & 153 & 153 & 153 \\
\hline Missing & 0 & 0 & 0 & 0 & 0 & 0 & 0 & 0 & 0 & 0 \\
\hline Mean & 3,76 & 2,76 & 3,44 & 9,97 & 3,53 & 3,77 & 2,83 & 3,25 & 13,39 & 23,35 \\
\hline Median & 4,00 & 3,00 & 4,00 & 10,00 & 4,00 & 4,00 & 3,00 & 3,00 & 14,00 & 25,00 \\
\hline Mode & 4 & 3 & 5 & 13 & 5 & 4 & 2 & 5 & 15 & 27 \\
\hline Std. Deviation & 1,075 & 1,207 & 1,342 & 3,062 & 1,323 & 1,161 & 1,266 & 1,567 & 4,280 & 6,959 \\
\hline
\end{tabular}

Tabulka 2 Základní popisná statistika výzkumného vzorku

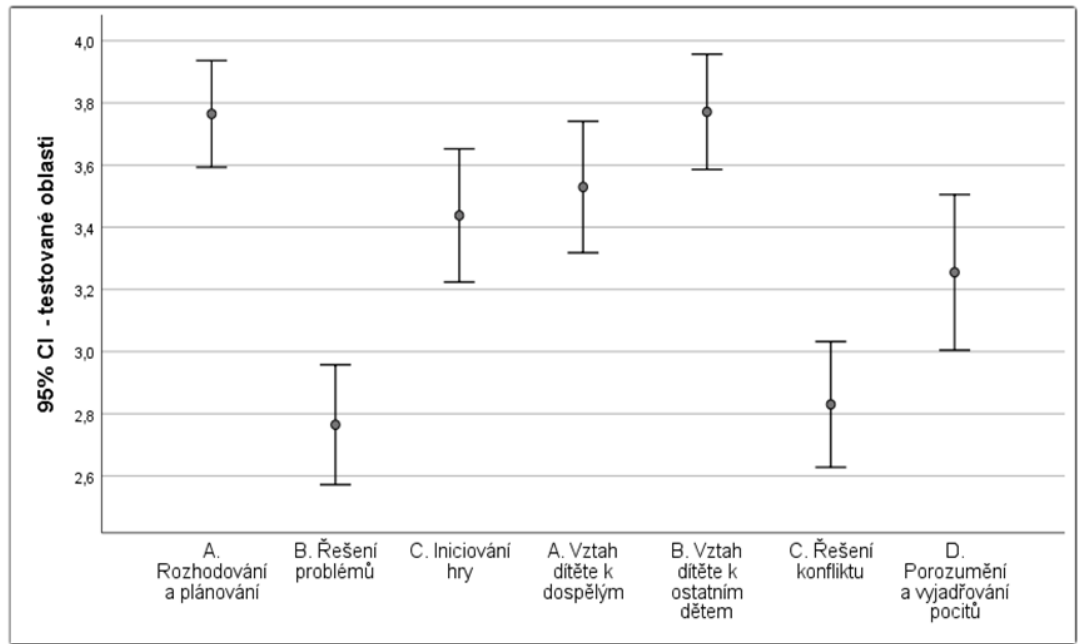

Graf 1 Interval spolehlivosti pro průměry jednotlivých položek

Dosažené skóre jsme dále vyhodnocovali v závislosti na věku dítěte, pohlaví dítěte, délce docházky do mateřské školy, počtu dětí ve třídě a věkového složení dětí ve třídě (heterogenní/homogenní).

\section{Věk dítěte}


Skóre jednotlivých věkových skupin ve sledovaných položkách ukazuje

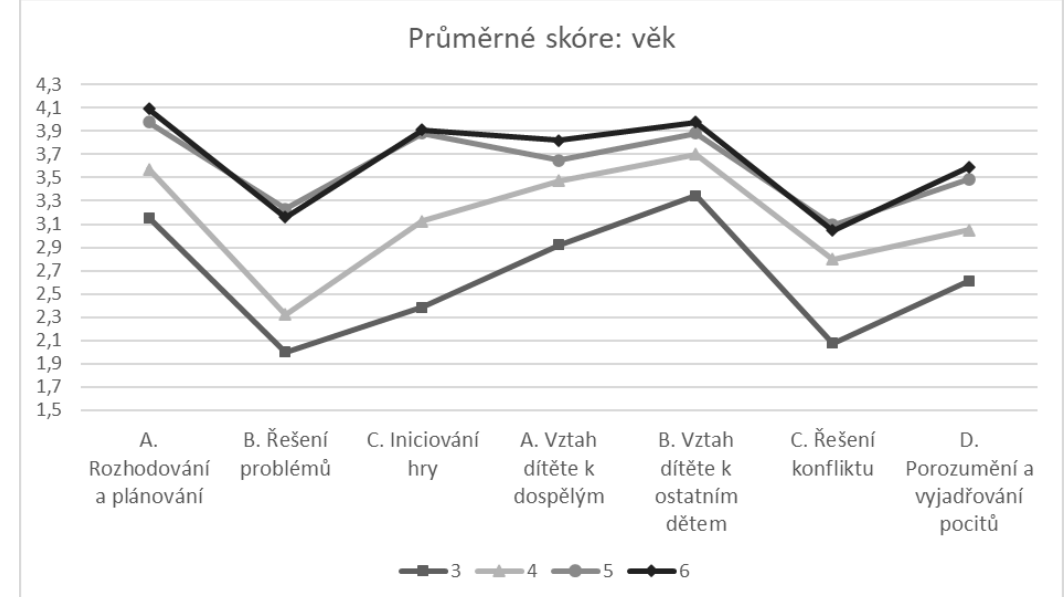

Graf 2,3. V závislosti na věku dítěte dosahovaly děti významně rozdílného skóre ve většině položek pozorovacího archu (Tabulka 3, ANOVA dle věku). Věk dítěte tedy ovlivňuje úroveň sociální kompetence dětí. Bonferroniho test poukázal na rozdíly mezi 3letými a 5 a 6letými dětmi v položkách Rozhodováni a plánování a Řešení konfliktů. Dále mezi 3 a 4letými a 5 a 6letými dětmi v položkách Řešení problémů a Iniciování hry. Statisticky významné rozdíly nejsou mezi dětmi 3letými a 4letými a mezi 5letými a 6letými.

$\mathrm{Na}$ hraně přijetí statistických hypotéz jsou rozdíly $\mathrm{v}$ položce Vztah $k$ dospělým v závislosti na věku. Děti 3leté dosahují nižšího skóre než děti 6leté, ale výsledek je věcně i statisticky nevýznamný. Děti se dále neliší v dosahovaném skóre v položkách Vztah ditěte $k$ ostatním dětem a v oblasti Porozuměni a vyjadřováni pocitů v závislosti na věku.

Můžeme shrnout, že děti 3leté dosahují v celkovém skóre významně nižšího skóre než děti 5leté a 6leté. $Z$ výsledků je patrná větší souvislost mezi věkem dítěte a dosaženým skórem v subtestu Iniciativa než v subtestu Sociální dovednosti. 


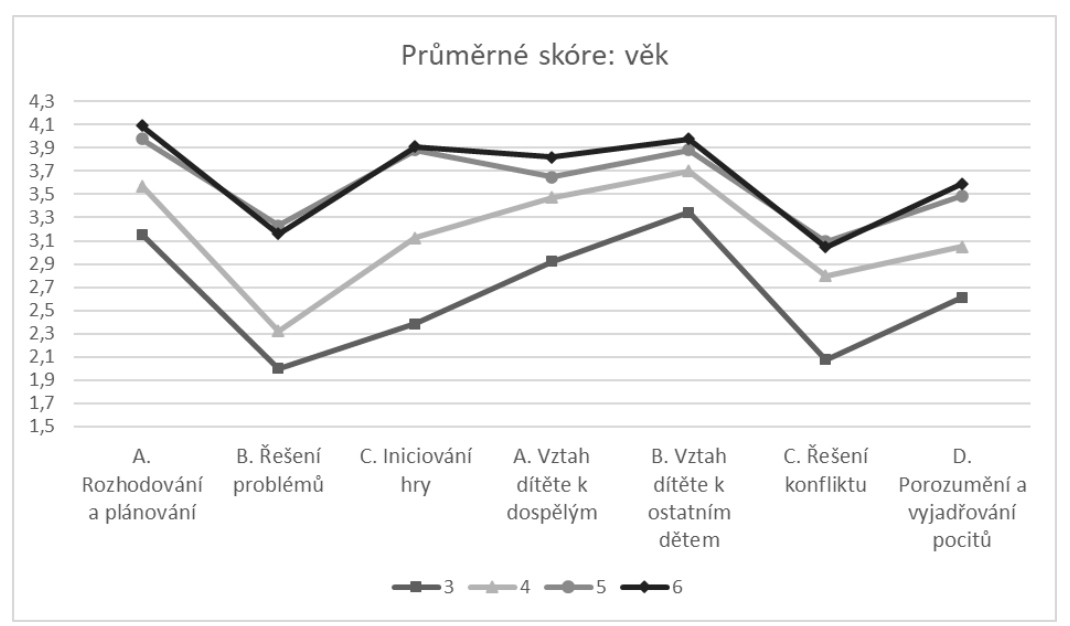

Graf 2 Závislost dosaženého skóre na věku dítěte

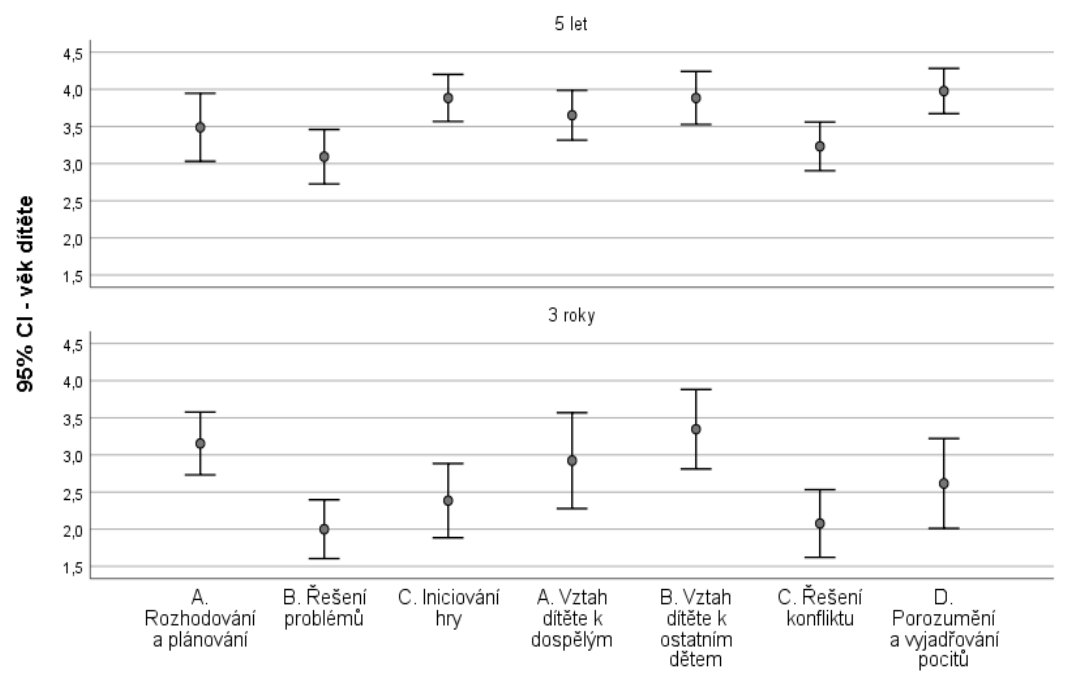

Graf 3 Interval spolehlivosti pro průměry jednotlivých položek dle věku 


\begin{tabular}{|c|c|c|c|c|c|c|}
\hline \multicolumn{7}{|c|}{ ANOVA Table } \\
\hline věk dítěte* & & $\begin{array}{l}\text { Sum of } \\
\text { Squares }\end{array}$ & df & $\begin{array}{c}\text { Mean } \\
\text { Square }\end{array}$ & $\mathrm{F}$ & Sig. \\
\hline \multirow{3}{*}{$\begin{array}{l}\text { A. Rozhodování a } \\
\text { plánování }\end{array}$} & Between Groups & 17,757 & 3 & 5,919 & 5,590 & 0,001 \\
\hline & Within Groups & 157,773 & 149 & 1,059 & & \\
\hline & Total & 175,529 & 152 & & & \\
\hline \multirow{3}{*}{ B. Řešení problémů } & Between Groups & 39,194 & 3 & 13,065 & 10,676 & 0,000 \\
\hline & Within Groups & 182,336 & 149 & 1,224 & & \\
\hline & Total & 221,529 & 152 & & & \\
\hline \multirow{3}{*}{ C. Iniciování hry } & Between Groups & 51,076 & 3 & 17,025 & 11,397 & 0,000 \\
\hline & Within Groups & 222,584 & 149 & 1,494 & & \\
\hline & Total & 273,660 & 152 & & & \\
\hline \multirow{3}{*}{ 1. Iniciativa -součet } & Between Groups & 305,886 & 3 & 101,962 & 13,577 & 0,000 \\
\hline & Within Groups & 1118,951 & 149 & 7,510 & & \\
\hline & Total & 1424,837 & 152 & & & \\
\hline \multirow{3}{*}{$\begin{array}{l}\text { A. Vztah dítěte k } \\
\text { dospělým }\end{array}$} & Between Groups & 13,984 & 3 & 4,661 & 2,755 & 0,045 \\
\hline & Within Groups & 252,134 & 149 & 1,692 & & \\
\hline & Total & 266,118 & 152 & & & \\
\hline \multirow{3}{*}{$\begin{array}{l}\text { B. Vztah dítěte k } \\
\text { ostatním dětem }\end{array}$} & Between Groups & 7,313 & 3 & 2,438 & 1,837 & 0,143 \\
\hline & Within Groups & 197,680 & 149 & 1,327 & & \\
\hline & Total & 204,993 & 152 & & & \\
\hline \multirow{3}{*}{ C. Řešení konfliktu } & Between Groups & 19,799 & 3 & 6,600 & 4,394 & 0,005 \\
\hline & Within Groups & 223,783 & 149 & 1,502 & & \\
\hline & Total & 243,582 & 152 & & & \\
\hline \multirow{3}{*}{$\begin{array}{l}\text { D. Porozumění a } \\
\text { vyjadřování pocitů }\end{array}$} & Between Groups & 19,624 & 3 & 6,541 & 2,758 & 0,044 \\
\hline & Within Groups & 353,434 & 149 & 2,372 & & \\
\hline & Total & 373,059 & 152 & & & \\
\hline \multirow{3}{*}{$\begin{array}{l}\text { 2. Sociální dovednosti - } \\
\text { součet }\end{array}$} & Between Groups & 229,098 & 3 & 76,366 & 4,453 & 0,005 \\
\hline & Within Groups & 2555,151 & 149 & 17,149 & & \\
\hline & Total & 2784,248 & 152 & & & \\
\hline \multirow{3}{*}{ součet celkem } & Between Groups & 1048,789 & 3 & 349,596 & 8,252 & 0,000 \\
\hline & Within Groups & 6312,153 & 149 & 42,363 & & \\
\hline & Total & 7360,941 & 152 & & & \\
\hline
\end{tabular}

Tabulka 3 Analýza rozptylu ANOVA dle věku dítěte

\section{Pohlaví dítěte}

Také pohlaví dítěte ovlivňuje skóre v pozorovaných oblastech. Ve všech sledovaných položkách pozorovacího archu dosahují chlapci nižšího skóre než děvčata (Figure 4,5). Kromě položky Řešení problémů se jedná o statisticky významné rozdíly (Tabulka 4).

Pohlaví dítěte má větší vliv na výsledky v subtestu Sociálních dovedností než v subtestu Iniciativa. 


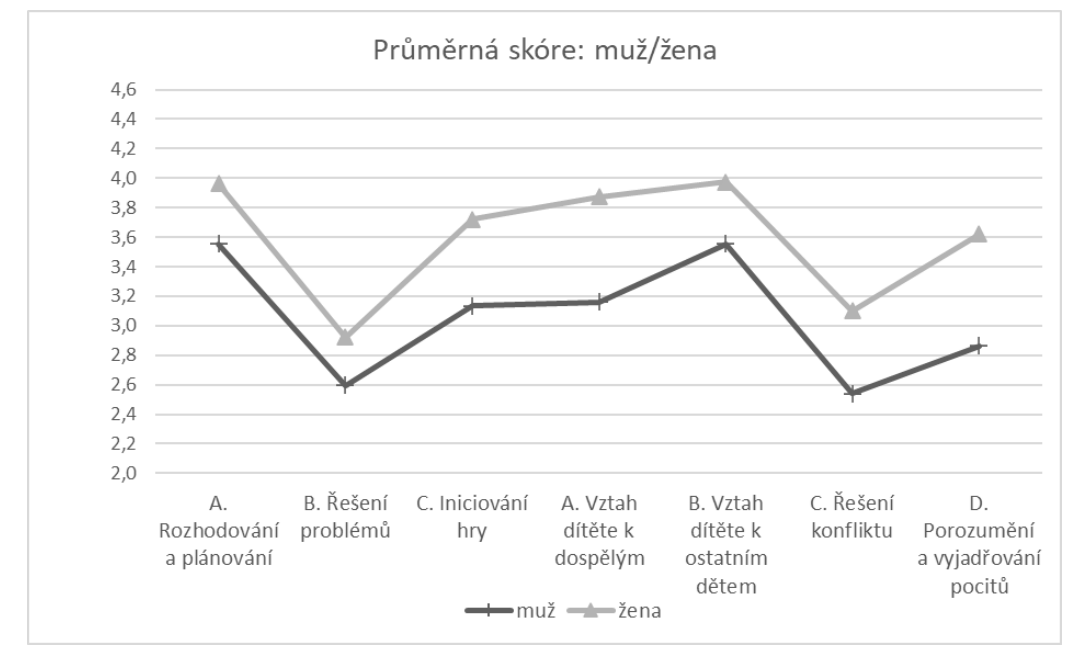

Graf 4 Závislost dosaženého skóre na pohlaví dítěte

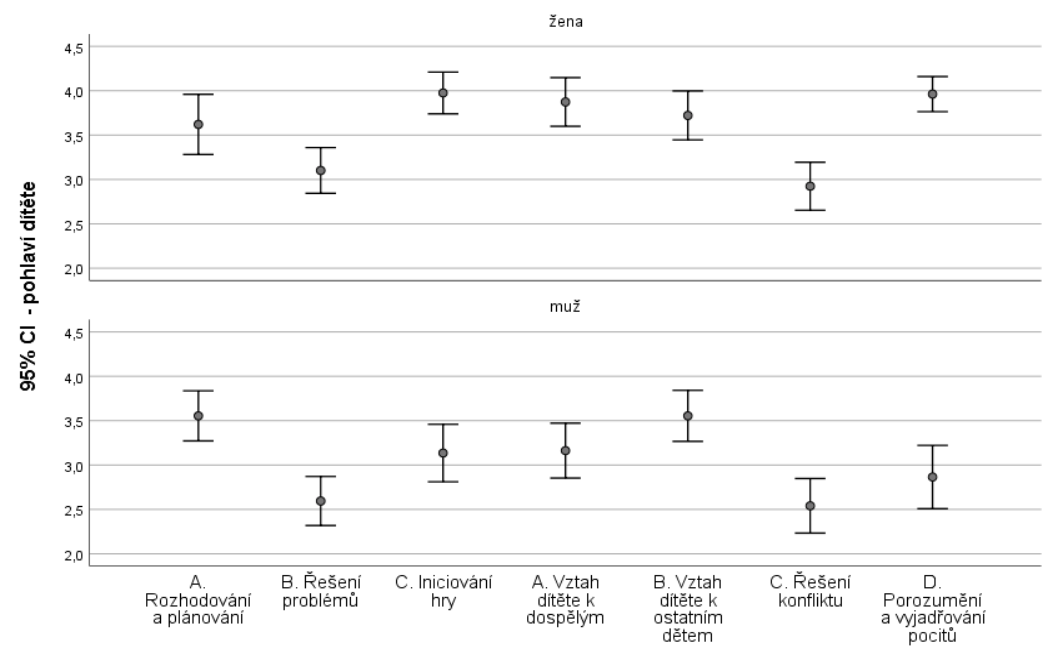

Graf 5 Interval spolehlivosti pro průměry jednotlivých položek dle pohlaví 


\begin{tabular}{|c|c|c|c|c|c|c|}
\hline \multicolumn{7}{|c|}{ ANOVA Table } \\
\hline \multicolumn{2}{|l|}{ pohlaví dítěte* } & $\begin{array}{l}\text { Sum of } \\
\text { Squares }\end{array}$ & $\mathrm{df}$ & $\begin{array}{l}\text { Mean } \\
\text { Square }\end{array}$ & $\mathrm{F}$ & Sig. \\
\hline \multirow{3}{*}{$\begin{array}{l}\text { A. Rozhodování a } \\
\text { plánování }\end{array}$} & Between Groups & 6,360 & 1 & 6,360 & 5,676 & 0,018 \\
\hline & Within Groups & 169,170 & 151 & 1,120 & & \\
\hline & Total & 175,529 & 152 & & & \\
\hline \multirow{3}{*}{ B. Řešení problémů } & Between Groups & 4,147 & 1 & 4,147 & 2,881 & 0,092 \\
\hline & Within Groups & 217,382 & 151 & 1,440 & & \\
\hline & Total & 221,529 & 152 & & & \\
\hline \multirow{3}{*}{ C. Iniciování hry } & Between Groups & 13,138 & 1 & 13,138 & 7,615 & 0,007 \\
\hline & Within Groups & 260,522 & 151 & 1,725 & & \\
\hline & Total & 273,660 & 152 & & & \\
\hline \multirow{3}{*}{ 1. Iniciativa -součet } & Between Groups & 66,961 & 1 & 66,961 & 7,446 & 0,007 \\
\hline & Within Groups & 1357,876 & 151 & 8,993 & & \\
\hline & Total & 1424,837 & 152 & & & \\
\hline \multirow{3}{*}{$\begin{array}{l}\text { A. Vztah dítěte k } \\
\text { dospělým }\end{array}$} & Between Groups & 19,329 & 1 & 19,329 & 11,827 & 0,001 \\
\hline & Within Groups & 246,788 & 151 & 1,634 & & \\
\hline & Total & 266,118 & 152 & & & \\
\hline \multirow{3}{*}{$\begin{array}{l}\text { B. Vztah dítěte } \mathrm{k} \\
\text { ostatním dětem }\end{array}$} & Between Groups & 6,760 & 1 & 6,760 & 5,150 & 0,025 \\
\hline & Within Groups & 198,233 & 151 & 1,313 & & \\
\hline & Total & 204,993 & 152 & & & \\
\hline \multirow{3}{*}{ C. Řešení konfliktu } & Between Groups & 12,013 & 1 & 12,013 & 7,834 & 0,006 \\
\hline & Within Groups & 231,568 & 151 & 1,534 & & \\
\hline & Total & 243,582 & 152 & & & \\
\hline \multirow{3}{*}{$\begin{array}{l}\text { D. Porozumění a } \\
\text { vyjadřování pocitů }\end{array}$} & Between Groups & 21,803 & 1 & 21,803 & 9,373 & 0,003 \\
\hline & Within Groups & 351,256 & 151 & 2,326 & & \\
\hline & Total & 373,059 & 152 & & & \\
\hline \multirow{3}{*}{$\begin{array}{l}\text { 2. Sociální dovednosti - } \\
\text { součet }\end{array}$} & Between Groups & 228,976 & 1 & 228,976 & 13,531 & 0,000 \\
\hline & Within Groups & 2555,272 & 151 & 16,922 & & \\
\hline & Total & 2784,248 & 152 & & & \\
\hline \multirow{3}{*}{ součet celkem } & Between Groups & 543,584 & 1 & 543,584 & 12,040 & 0,001 \\
\hline & Within Groups & 6817,357 & 151 & 45,148 & & \\
\hline & Total & 7360,941 & 152 & & & \\
\hline
\end{tabular}

Tabulka 4 Analýza rozptylu ANOVA dle pohlaví dítěte

\section{Délka docházky do mateřské školy}

Průměrná skóre $\mathrm{v}$ jednotlivých položkách pro dané skupiny dětí zachycuje graf

\section{Průměrná skóre: délka docházky}

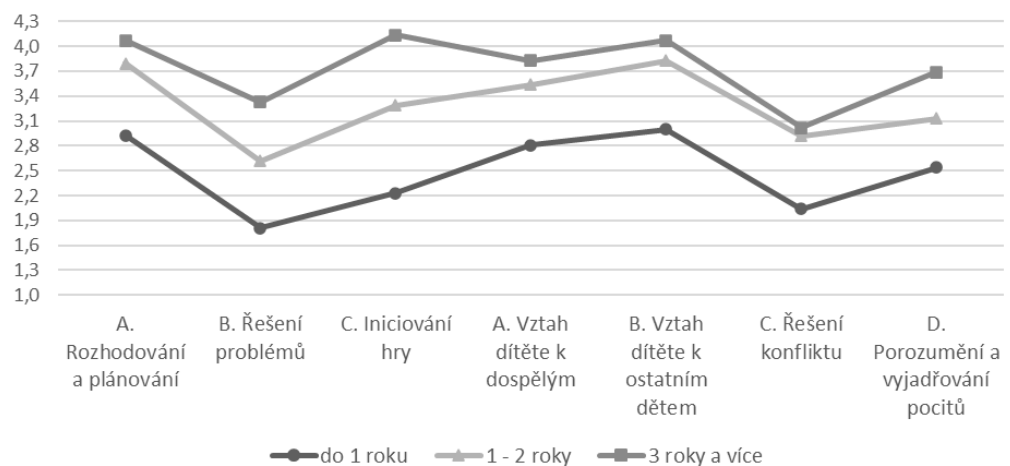


Graf ). Děti dosahovaly i významně rozdílného skóre u všech položek v závislosti na délce docházky do mateřské školy (Tabulka 5). Výstupy Bonferroniho testu ukázaly, že děti $\mathrm{s}$ docházkou do 1 roku dosahují významně nižšího skóre v položce Rozhodování a plánování, v položce Iniciování hry, v položce Vztah ditěte $k$ ostatním dětem, v položce Řešení konfliktu a v položce Porozumění a vyjadřování pocitů oproti dětem $\mathrm{s}$ docházkou 1-2 roky i 3 roky a více. Děti s docházkou do 1 roku a s děti docházkou 1-2 roky dosáhly významně nižšího skóre v položce Řešení problémů oproti dětem s docházkou 3 roky a více. Děti s docházkou 1-2 roky dosáhly významně nižšího skóre $\mathrm{v}$ položce Iniciováni hry oproti dětem $\mathrm{s}$ docházkou 3 roky a více. Děti s docházkou do 1 roku dosáhly významně nižšího skóre $\mathrm{v}$ položce Vztah ditěte $k$ dospělým oproti dětem s docházkou 3 roky a více.

V součtu subtestu Sociální dovednosti dosahují významně nižšího skóre děti s docházkou do 1 roku oproti dětem $\mathrm{s}$ docházkou 1-2 roky a 3 roky a více. Délka docházky do mateřské školy více koreluje s výsledky subtestu Iniciativa než subtestu Sociální dovednosti.

Děti dosahují významně odlišného celkového skóre $\mathrm{v}$ závislosti na délce docházky do MŠ. Statisticky významné rozdíly jsou mezi všemi skupinami. Délka docházky vysvětluje 19,1 \% variability celkového testového skóre.

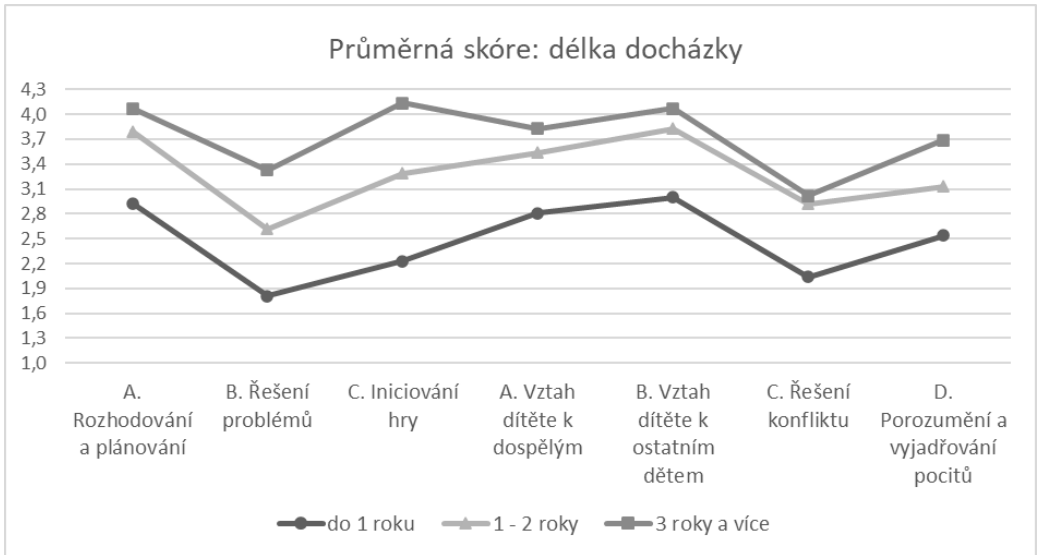

Graf 6 Závislost dosaženého skóre na délce docházky do MŠ 


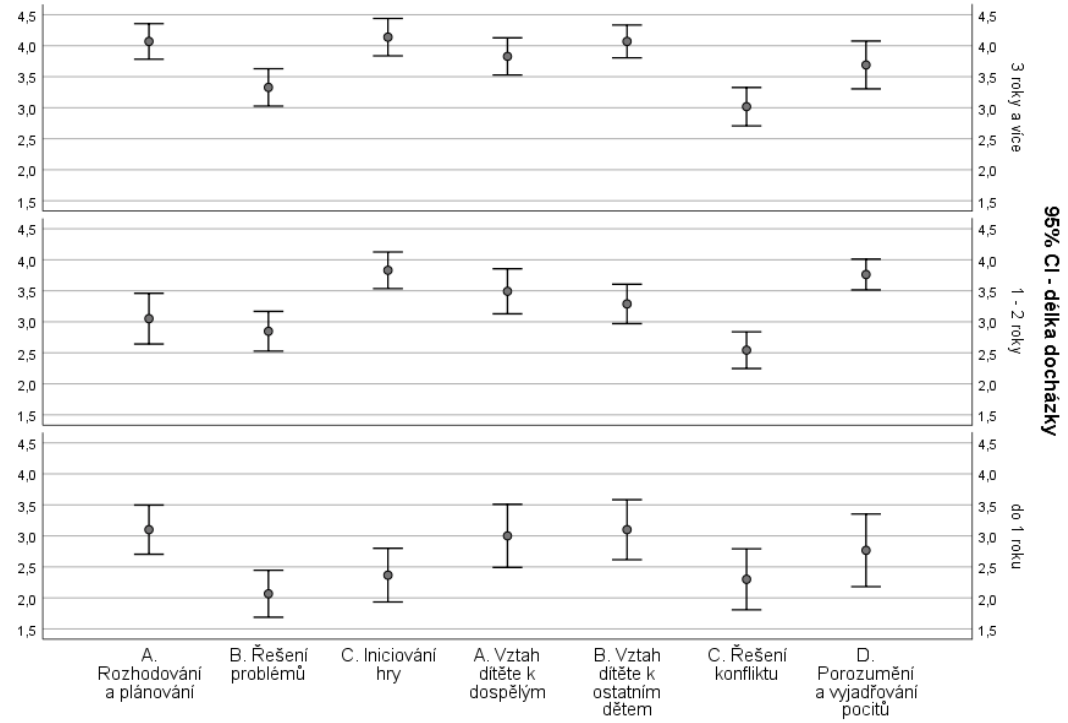

Graf 7 Interval spolehlivosti pro průměry jednotlivých položek dle délky docházky 


\begin{tabular}{|c|c|c|c|c|c|c|}
\hline \multicolumn{7}{|c|}{ ANOVA Table } \\
\hline \multicolumn{2}{|l|}{ délka docházky* } & $\begin{array}{l}\text { Sum of } \\
\text { Squares }\end{array}$ & df & $\begin{array}{l}\text { Mean } \\
\text { Square }\end{array}$ & $\mathrm{F}$ & Sig. \\
\hline \multirow{3}{*}{$\begin{array}{l}\text { A. Rozhodování a } \\
\text { plánování }\end{array}$} & Between Groups & 24,808 & 3 & 8,269 & 8,175 & 0,000 \\
\hline & Within Groups & 150,721 & 149 & 1,012 & & \\
\hline & Total & 175,529 & 152 & & & \\
\hline \multirow{3}{*}{ B. Řešení problémů } & Between Groups & 43,858 & 3 & 14,619 & 12,260 & 0,000 \\
\hline & Within Groups & 177,671 & 149 & 1,192 & & \\
\hline & Total & 221,529 & 152 & & & \\
\hline \multirow{3}{*}{ C. Iniciování hry } & Between Groups & 67,791 & 3 & 22,597 & 16,355 & 0,000 \\
\hline & Within Groups & 205,869 & 149 & 1,382 & & \\
\hline & Total & 273,660 & 152 & & & \\
\hline \multirow{3}{*}{ 1. Iniciativa -součet } & Between Groups & 384,841 & 3 & 128,280 & 18,379 & 0,000 \\
\hline & Within Groups & 1039,996 & 149 & 6,980 & & \\
\hline & Total & 1424,837 & 152 & & & \\
\hline \multirow{3}{*}{$\begin{array}{l}\text { A. Vztah dítěte } \mathrm{k} \\
\text { dospělým }\end{array}$} & Between Groups & 18,819 & 3 & 6,273 & 3,780 & 0,012 \\
\hline & Within Groups & 247,298 & 149 & 1,660 & & \\
\hline & Total & 266,118 & 152 & & & \\
\hline \multirow{3}{*}{$\begin{array}{l}\text { B. Vztah dítěte } \mathrm{k} \\
\text { ostatním dětem }\end{array}$} & Between Groups & 20,857 & 3 & 6,952 & 5,626 & 0,001 \\
\hline & Within Groups & 184,137 & 149 & 1,236 & & \\
\hline & Total & 204,993 & 152 & & & \\
\hline \multirow{3}{*}{ C. Řešení konfliktu } & Between Groups & 21,534 & 3 & 7,178 & 4,817 & 0,003 \\
\hline & Within Groups & 222,047 & 149 & 1,490 & & \\
\hline & Total & 243,582 & 152 & & & \\
\hline \multirow{3}{*}{$\begin{array}{l}\text { D. Porozumění a } \\
\text { vyjadřování pocitů }\end{array}$} & Between Groups & 25,699 & 3 & 8,566 & 3,675 & 0,014 \\
\hline & Within Groups & 347,359 & 149 & 2,331 & & \\
\hline & Total & 373,059 & 152 & & & \\
\hline \multirow{3}{*}{$\begin{array}{l}\text { 2. Sociální dovednosti - } \\
\text { součet }\end{array}$} & Between Groups & 325,612 & 3 & 108,537 & \begin{tabular}{l|}
6,578 \\
\end{tabular} & 0,000 \\
\hline & Within Groups & 2458,636 & 149 & 16,501 & & \\
\hline & Total & 2784,248 & 152 & & & \\
\hline \multirow{3}{*}{ součet celkem } & Between Groups & 1407,938 & 3 & 469,313 & 11,747 & 0,000 \\
\hline & Within Groups & 5953,003 & 149 & 39,953 & & \\
\hline & Total & 7360,941 & 152 & & & \\
\hline
\end{tabular}

Tabulka 5 Analýza rozptylu ANOVA dle délky docházky do MŠ

\section{Věkové složení třídy}

S výjimkou položky Porozuměni a vyjadřováni emocí byl průměr skóre dětí $\mathrm{z}$ věkově heterogenních tríid

vyšší

Průměrné skóre: věkové složení třídy

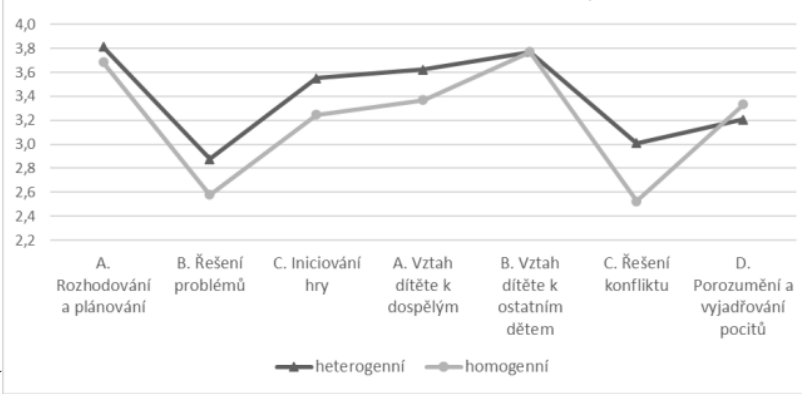

Graf ). Pouze u položky Řešení konfliktů se jedná o výsledek statisticky významný, věcně ovšem jen slabý (Table 6). 


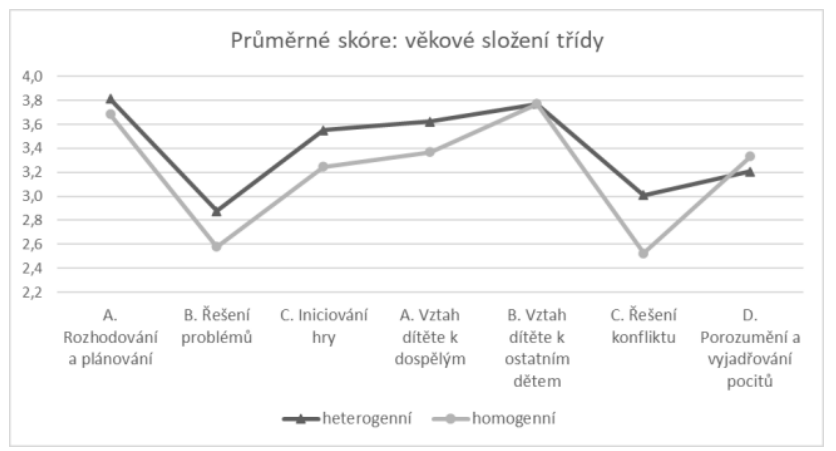

Graf 8 Závislost dosaženého skóre na věkovém složení třídy

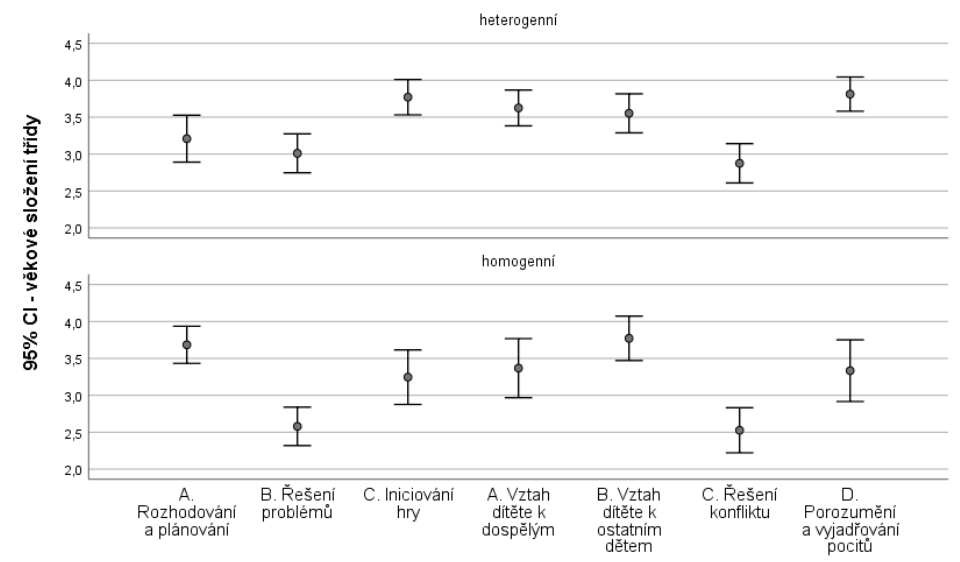

Graf 9 Interval spolehlivosti pro průměry jednotlivých položek dle věkového složení třídy 


\begin{tabular}{|c|c|c|c|c|c|c|}
\hline \multicolumn{7}{|c|}{ ANOVA Table } \\
\hline \multicolumn{2}{|l|}{ složení třídy* } & $\begin{array}{l}\text { Sum of } \\
\text { Squares }\end{array}$ & df & $\begin{array}{l}\text { Mean } \\
\text { Square }\end{array}$ & $\mathrm{F}$ & Sig. \\
\hline \multirow{3}{*}{$\begin{array}{l}\text { A. Rozhodování a } \\
\text { plánování }\end{array}$} & Between Groups & 0,589 & 1 & 0,589 & 0,508 & 0,477 \\
\hline & Within Groups & 174,941 & 151 & 1,159 & & \\
\hline & Total & 175,529 & 152 & & & \\
\hline \multirow{3}{*}{ B. Řešení problémů } & Between Groups & 3,135 & 1 & 3,135 & 2,167 & 0,143 \\
\hline & Within Groups & 218,395 & 151 & 1,446 & & \\
\hline & Total & 221,529 & 152 & & & \\
\hline \multirow{3}{*}{ C. Iniciování hry } & Between Groups & 3,359 & 1 & 3,359 & 1,877 & 0,173 \\
\hline & Within Groups & 270,301 & 151 & 1,790 & & \\
\hline & Total & 273,660 & 152 & & & \\
\hline \multirow{3}{*}{ 1. Iniciativa -součet } & Between Groups & 19,101 & 1 & 19,101 & 2,052 & 0,154 \\
\hline & Within Groups & 1405,735 & 151 & 9,310 & & \\
\hline & Total & 1424,837 & 152 & & & \\
\hline \multirow{3}{*}{$\begin{array}{l}\text { A. Vztah dítěte } \mathrm{k} \\
\text { dospělým }\end{array}$} & Between Groups & 2,354 & 1 & 2,354 & 1,348 & 0,247 \\
\hline & Within Groups & 263,763 & 151 & 1,747 & & \\
\hline & Total & 266,118 & 152 & & & \\
\hline \multirow{3}{*}{$\begin{array}{l}\text { B. Vztah dítěte } \mathrm{k} \\
\text { ostatním dětem }\end{array}$} & Between Groups & 0,000 & 1 & 0,000 & 0,000 & 0,996 \\
\hline & Within Groups & 204,993 & 151 & 1,358 & & \\
\hline & Total & 204,993 & 152 & & & \\
\hline \multirow{3}{*}{ C. Řešení konfliktu } & Between Groups & 8,382 & 1 & 8,382 & 5,381 & 0,022 \\
\hline & Within Groups & 235,200 & 151 & 1,558 & & \\
\hline & Total & 243,582 & 152 & & & \\
\hline \multirow{3}{*}{$\begin{array}{l}\text { D. Porozumění a } \\
\text { vyjadřování pocitů }\end{array}$} & Between Groups & 0,559 & 1 & 0,559 & 0,227 & 0,635 \\
\hline & Within Groups & 372,500 & 151 & 2,467 & & \\
\hline & Total & 373,059 & 152 & & & \\
\hline \multirow{3}{*}{$\begin{array}{l}\text { 2. Sociální dovednosti } \\
\text { součet }\end{array}$} & Between Groups & 13,509 & 1 & 13,509 & 0,736 & 0,392 \\
\hline & Within Groups & 2770,740 & 151 & 18,349 & & \\
\hline & Total & 2784,248 & 152 & & & \\
\hline \multirow{3}{*}{ součet celkem } & Between Groups & 64,737 & 1 & 64,737 & 1,340 & 0,249 \\
\hline & Within Groups & 7296,204 & 151 & 48,319 & & \\
\hline & Total & 7360,941 & 152 & & & \\
\hline
\end{tabular}

Table 6 Analýza rozptylu ANOVA dle věkového složení třídy

\section{Možnosti využití pozorovacího archu}

Předpoklad P2, tj. vzájemný vztah mezi dosaženými skóry v jednotlivých subtestech pozorovacího archu, byl analyzován pomocí Pearsonova korelačního koeficientu, který prezentuje př́íslušná matice (Tabulka 7). 


\begin{tabular}{|c|c|c|c|c|c|c|c|c|}
\hline \multicolumn{9}{|c|}{ Correlations } \\
\hline & & A & & C. & A. & B. & c. & \\
\hline & & $\begin{array}{c}\text { Rozhodováni } \\
\text { a plánování }\end{array}$ & $\begin{array}{l}\text { Řešení } \\
\text { problémů }\end{array}$ & Iniciováni hry & $\begin{array}{c}\text { Vztah ditěte } k \\
\text { dospělým }\end{array}$ & $\begin{array}{c}\text { Vztah ditěte k } \\
\text { ostatním } \\
\text { dětem }\end{array}$ & $\begin{array}{c}\text { Řešení } \\
\text { konfliktu }\end{array}$ & $\begin{array}{c}\text { Porozumění a } \\
\text { vyjadřování } \\
\text { pocitů }\end{array}$ \\
\hline \multirow{2}{*}{\begin{tabular}{|l} 
A Rozhodování \\
a plánování
\end{tabular}} & Pearson Correl. & 1 & $637^{* 1}$ &, $533^{* \prime}$ &, $505^{* \prime}$ & ,563"* &, $570^{*}$ &, $548^{* \prime}$ \\
\hline & Sig. (2-tailed) & & 0,000 & 0,000 & 0,000 & 0,000 & 0,000 & 0,000 \\
\hline \multirow{2}{*}{$\begin{array}{l}\text { B. Řešení } \\
\text { problémů }\end{array}$} & Pearson Correl. & ,637" & 1 &, $547^{* \prime}$ &, $544^{*}$ &, $510^{* *}$ & ,598" &, $561^{*}$ \\
\hline & Sig. (2-tailed) & 0,000 & & 0,000 & 0,000 & 0,000 & 0,000 & 0,000 \\
\hline \multirow[t]{2}{*}{ C. Iniciování hry } & Pearson Correl. &, $533^{* *}$ & ,547" & 1 &, $521 "$ & ,538* &, $524^{* \prime}$ & ,494" \\
\hline & Sig. (2-tailed) & 0,000 & 0,000 & & 0,000 & 0,000 & 0,000 & 0,000 \\
\hline \multirow{2}{*}{$\begin{array}{l}\text { A Vztah ditěte } \mathrm{k} \\
\text { dospělým }\end{array}$} & Pearson Correl. &, $505^{* \prime}$ &, $544^{n+1}$ &, $521^{* \prime}$ & 1 &, $533^{n+1}$ &, $514^{*}$ &, $560^{\circ}$ \\
\hline & Sig. (2-tailed) & 0,000 & 0,000 & 0,000 & & 0,000 & 0,000 & 0,000 \\
\hline \multirow{2}{*}{$\begin{array}{l}\text { B. Vztah ditěte } k \\
\text { ostatním dětem }\end{array}$} & k Pearson Correl. &, $563^{* \prime}$ &, $510^{*}$ &, $538^{* \prime}$ &, $533^{*}$ & 1 & ,493" &, $506^{\prime \prime}$ \\
\hline & Sig. (2-tailed) & 0,000 & 0,000 & 0,000 & 0,000 & & 0,000 & 0,000 \\
\hline \multirow{2}{*}{\begin{tabular}{|l} 
C. Řešení \\
konfliktu
\end{tabular}} & Pearson Correl. &, $570^{*}$ &, $598^{\prime \prime}$ &, $524^{* \prime}$ &, $514^{*}$ &, $493^{\prime \prime}$ & 1 &, $553^{\prime \prime}$ \\
\hline & Sig. (2-tailed) & 0,000 & 0,000 & 0,000 & 0,000 & 0,000 & & 0,000 \\
\hline \multirow{2}{*}{$\begin{array}{l}\text { D. Porozumění } \\
\text { a vyjadřování } \\
\text { pocitủ }\end{array}$} & Pearson Correl. &, $548^{*}$ &, $561^{\prime \prime}$ &, $494^{* \prime}$ &, $560^{*}$ &, $506^{\prime \prime}$ &, $553^{*}$ & 1 \\
\hline & Sig. (2-tailed) & 0,000 & 0,000 & 0,000 & 0,000 & 0,000 & 0,000 & \\
\hline \multicolumn{9}{|c|}{${ }^{* \star}$. Correlation is significant at the 0.01 level (2-tailed). } \\
\hline & & & & & & & & \\
\hline
\end{tabular}

Tabulka 7 Matice Pearsonova korelačního koeficientu jednotlivých položek

\section{Závěr}

V naší studii jsme se soustředili na to, abychom poskytli učitelům mateřských škol relevantní nástroj, který by jim pomohl diagnostikovat úroveň rozvoje sociálních kompetencí u dětí předškolního věku od začátku předškolní docházky až po vstup do základního vzdělávání. Proto jsme modifikovali pro české prostředí a pozorovací arch COR Observation Items - Preschool Child Observation Record (2003), ze kterého jsme vybrali dva subtesty, které nejvíce odpovídaly cílům výzkumu (Iniciativa a Sociální vztahy).

Vlastnosti představovaného výzkumného nástroje jsme zjišt’ovali pomocí metod exploračního výzkumu. Vzhledem k tomu, že jde o pilotní průzkum a zkoumaný soubor nesplňuje parametry platné pro reprezentativní vzorek, interpretujeme data vzhledem ke zkoumanému vzorku. S ohledem na design výzkumu jsme si stanovili výzkumné předpoklady, jejichž výsledky prezentujeme. Výsledky exploračního výzkumu pak odhalily zajímavé otázky, které by se mohli stát součástí hlubších analýz v oblasti rozvoje sociálních kompetencí u dětí před zahájením školní docházky.

Z podrobných analýz exploračního šetření vyplývá, že nástroj vykazuje v našem výběrovém souboru dobré testové vlastnosti (tj. konstruktovou validitu i reliabilitu - děti z různých MŠ zahrnutých do výzkumu dosahují shodných výsledků), a lze jej proto doporučit jako vhodný a efektivní nástroj pro zjištování stupně rozvoje sociálních kompetencí u předškolních dětí. Potvrdilo se, že úroveň nástrojem zjištovaných sociálních kompetencí roste $\mathrm{s}$ věkem a délkou docházky do mateřské školy, souvisí s pohlavím a věkovým složením třídy. Věk dítěte a délka docházky do mateřské školy korelují výrazně více se subtestem Iniciativa než se subtestem Sociální dovednosti. U pohlaví dítěte je tomu naopak a míra korelace je výrazně menší. 
Není bez zajímavosti, že se neprokázala souvislost s počtem dětí ve tř́́dě. Lze tedy konstatovat, že počet dětí ve trrídě neměl v našem vzorku souvislost s rozvojem sociálních kompetencí. Zdá se tedy, že sociální kompetence se rozvijí stejně nebo podobně ve trí́dě s menším počtem dětí jako ve větším kolektivu

Na druhé straně šetření zjištuje statisticky významnou souvislost $\mathrm{s}$ věkovým složením třídy, v našem vzorku nalézáme těsnější vztah mezi rozvojem kompetencí ve tř̌́dě věkově heterogenní (tř̌ída složená z dětí různého) než ve trrídě věkově homogenní (třída složená z dětí stejného věku). Nejnižšího skóre dosahovali respondenti v oblasti/položkách Řešeni problémů a Řešení konfliktů. Náš pilotní výzkum naznačuje, že v oblasti řešení konfliktů a problémů děti navzdory rostoucímu věku nedosahují potřebné úrovně sociální kompetence. O př́činách nelze $\mathrm{v}$ současné chvíli relevantně diskutovat, ale hodláme se tomuto problému nadále věnovat.

Ve druhé fázi ověřování pozorovacího archu jsme se soustředili na to, zda se oba analyzované subtesty prolínají a zda jednotlivé položky spolu vzájemně souvisí. Vycházeli jsme s premisy, že se zvyšující se úrovní (skórem) dovednosti $\mathrm{v}$ jednom subtestu bude růst úroveň (skóre) dovednosti v subtestu druhém. Domnívali jsme se na základě teoretických studií (odkazy), že děti s vyšší sociální inteligencí nebo již rozvinutými sociální kompetencemi (jež rostou s věkem) skórují v jednotlivých subtestech významně lépe než děti s méně rozvinutými sociálními kompetenci, tj. pravděpodobně děti mladší. $Z$ výsledků statistických analýz vyplynulo, že s růstem dosažené úrovně $\mathrm{v}$ jedné položce subtestu rostou i položky $\mathrm{v}$ druhém subtestu. Korelační vazby mimo výše uvedenou tezi potvrzují, že i když jednotlivé subtesty baterie měří velmi specifické sociální dovednosti, všechny se vztahují (a tedy měří) $\mathrm{k}$ jednomu společnému (nadřazenému) konstruktu „sociální kompetence.“

Závěrem můžeme konstatovat, že naše výzkumné předpoklady P1 i P2 byly oprávněné a mohou se stát podpůrnými výzkumnými zjištěními pro formulování hypotéz $\mathrm{v}$ budoucích výzkumech prováděných $\mathrm{v}$ této oblasti. Námi předložený a modifikovaný nástroj vykazuje dobré testové vlastnosti (validitu a reliabilitu) a lze jej doporučit pro identifikaci stupně rozvoje sociálních kompetencí v mateřské škole. Pilotní výzkum otevřel další otázky, které naznačují, že v rozvoji sociálních kompetencí existují faktory, které mohou progres jak podpořit, tak i naopak zbrzdit, nebo dojít $\mathrm{k}$ jeho stagnaci.

\section{Limity výzkumu}

Hlavním zdrojem omezení v naší studii je menší výzkumný vzorek, který byl způsoben, náročností výzkumu. Do výzkumu nebyly reprezentativně zahrnuty všechny mateřské školy v České republice, bylo vybráno 42 mateřských škol, což může být také zdrojem zkreslení, výsledky budou dále konfrontovány. Nicméně získaná data prokazují, že validita nástroje je dobrá a přináší vítanou pomoc pro učitele $\mathrm{v}$ oblasti diagnostiky sociálních kompetencí, který v současné době pro využití v pedagogické praxi není $\mathrm{k} \mathrm{u}$ nás dispozici.

\section{Bibliographic references}


BANDURA, A. 1998. Self-efficacy: The exercise of control. New York: Freeman.

BENESON, J. - DWECK, C. S. 1986. The development of trait explanation and self-evaluations in the academic and social domains. In: Child Development, n. 57, pp. 1179-1189.

DECI, E. L. - RYAN, R. M. 1980. The empirical exploration of intrinsic motivational processes. In: L. Berkowitz (Ed.), Advances in experimental social psychology, pp. 39-80. New York: Academic Press.

DWECK, C. S. 2002. The development of ability conceptions. In: A. Wigfield - J. S. Eccles (Eds.), Development of achievement motivation, pp. 57-88. San Diego, CA: Academic Press.

ECCLES, J. S. - WIGFIELD, A. - HAROLD, R. - BLUMENFELD, P. B. 1993. Age and gender differences in children's self- and task perceptions during elementary school. In: Child Development, n. 64, pp. 830-847.

ELLIOT, A. J. 1997. Integrating the "classic" and "contemporary" approaches to achievement motivation: A hierarchical model of achievement motivation. In: M. Maehr \& P. Pintrich (Eds.), Advances in motivation and achievement, n. 10, pp. 243-279. Greenwich, CT: JAI Press.

FREY, K. S. - RUBLE, D. N. 1985. What children say when the teacher is not around: Conflicting goals in social comparison and performance assessment in the classroom. In: Journal of Personality and Social Psychology, n. 48, pp. 550-562.

HECKHAUSEN, J. - HECKHAUSEN, H. (Eds.). 2008. Motivation and action. New York: Cambridge University Press. vol. 22.

HELUS, Z. 2015. Sociální psychologie pro pedagogy. 1. vyd. Praha: Grada. ISBN 978-80-247-4674-6.

HELUS, Z. 2009. Dite v osobnostnim pojeti: obrat k diteti jako vyzva a ukol pro ucitele i rodice. Praha: Portal. ISBN 978-80-7367-628-5.

HEYMAN, D. - DWECK, C. S. - CAIN, L. 1992. Young children's vulnerability to self-blame and helplessness. In: Child Development, n. 63, pp. 391-403.

HEYMAN, D. - GEE, C. L. - GILES, J. W. 2003. Preschool children's reasoning about ability. In: Child Development, n. 74, pp. 516-534.

MATEJCEK, Z. 2005. Prvnich 6 let ve vyvoji a vychove ditete: normy vyvoje a vyvojove milniky z pohledu psychologa: zakladni dusevni potreby ditete: dite a lidsky svet. Praha: Grada. ISBN 978-80-247-0870-6.

MCADAMS, D. P. - VAILLANT, G. E. 1982. Intimacy motivation and psychosocial adjustment: A longitudinal study. In: Journal of Personality Assessment, n. 46, pp. 586-593.

MEHRABIAN, A. 1970. The development and validation of measures of affiliative tendency and sensitivity to rejection. In: Educational and Psychological Measurement, n. 30, pp. 417-428.

NICHOLLS, J. G. 1984. Achievement motivation: Conceptions of ability, subjective experience, task choice, and performance. In: Psychological Review, n. 91, pp. 328-346.

OPRAVILOVA, E. 2016. Predskolni pedagogika. Praha: Grada. ISBN 97880-247-5107-8. 
Ramcovy vzdelavaci program pro predskolni vzdelavani. 2018. Praha: MSMT.

SCHULER, J. 2002. Ein hierarchisches Modell der Anschlussmotivation: Hoffnung-auf-Anschluss und Furcht-vor-Zuruckweisung und die Selbstregulation von Zielsetzungen. Doctoral dissertation, University of Wuppertal, Germany.

STIPEK, D. - DANIELS, D. 1990. Children's use of dispositional attributions in predicting the performance and behavior of classmates. In: Journal of Applied Developmental Psychology, n. 11, pp. 13-28.

STIPEK, D. - TANNATT, L. 1984. Children's judgments of their own and peers' academic competence. In: Journal of Educational Psychology, n. 76, pp. 75-84.

SVOBODOVA, E. a kol. 2017. Osobnost predskolniho pedagoga: sebereflexe, socialni kompetence a jejich rozvijeni. Praha: Portal. ISBN 97880-262-1243-0.

SYSLOVA, Z. 2013. Profesni kompetence ucitele materske skoly. Vyd. 1. Praha: Grada. ISBN 978-80-247-4309-7.

SYSLOVA, Z. 2017. Ucitel v predskolnim vzdelavani a jeho priprava na profesi. Brno: Masarykova univerzita. ISBN 978-80-210-8475-9.

SVARICEK, R. a kol. 2014. Kvalitativní výzkum v pedagogických vědách. Praha: Portal, 2014. ISBN 978-80-262-0644-6.

VAGNEROVA, M. 2012. Vyvojova psychologie. Detstvi a dospivani. Praha: Karolinum Press. ISBN 9788024621531.

WINTER, D. G. 1993. Power, affiliation, and war: Three tests of a motivational model. In:Journal of Personality and Social Psychology, n. 65, pp. 532-545.

YUSSEN, S. - KANE, P. 1985. Children's conceptions of intelligence. In: S. R. Yussen (Ed.), The growth of reflection in children. pp. 207-241. New York: Academic Press.

The COR Observation Items Preschool Child Observation Record. 2003. Available online: http://prekese.dadeschools.net/docs/ForTeachers/TeacherHandbook/appendixH/H\%20CORObservationItem sPK.pdf

Mgr. Kateřina Kubíková, Ph.D.

University of West Bohemia, Faculty of Education, Department of

Psychology

Univerzitní 2732/8, Plzeň

Czech Republic

kubikovk@kps.zcu.cz

Mgr. Milan Podpera, Ph.D.

University of West Bohemia,

Faculty of Education,

Department of Education

Plzeň

Czech Republic 
mpodpera@kpg.zcu.cz

Mgr. Aneta Boháčová, Ph.D.

University of West Bohemia, Faculty of Education, Department of Psychology

Univerzitní 2732/8, Plzeň

Czech Republic

bohacova@kps.zcu.cz 